\title{
H-CRRETAWAC-OH, a Lead Structure for the Development of Radiotracer Targeting Integrin $\alpha_{5} \beta_{1}$ ?
}

\author{
Roland Haubner, ${ }^{1}$ Simone Maschauer, ${ }^{2}$ Jürgen Einsiedel, ${ }^{3}$ Iris E. Eder, ${ }^{4}$ Christine Rangger, ${ }^{1}$ \\ Peter Gmeiner, ${ }^{3}$ Irene J. Virgolini, ${ }^{1}$ and Olaf Prante ${ }^{2}$ \\ ${ }^{1}$ Department of Nuclear Medicine, Innsbruck Medical University, Anichstraße 35, 6020 Innsbruck, Austria \\ ${ }^{2}$ Department of Nuclear Medicine, Molecular Imaging and Radiochemistry, Friedrich-Alexander University Erlangen-Nürnberg (FAU), \\ Schwabachanlage 6, 91054 Erlangen, Germany \\ ${ }^{3}$ Department of Chemistry and Pharmacy, Emil Fischer Center, Friedrich-Alexander University Erlangen-Nürnberg (FAU), \\ Schuhstraße 19, 91052 Erlangen, Germany \\ ${ }^{4}$ Department of Urology, Innsbruck Medical University, Anichstraße 35, 6020 Innsbruck, Austria
}

Correspondence should be addressed to Roland Haubner; roland.haubner@i-med.ac.at

Received 25 April 2014; Accepted 24 May 2014; Published 13 October 2014

Academic Editor: Patrick Riss

Copyright (C) 2014 Roland Haubner et al. This is an open access article distributed under the Creative Commons Attribution License, which permits unrestricted use, distribution, and reproduction in any medium, provided the original work is properly cited.

\begin{abstract}
Imaging of angiogenic processes is of great interest in preclinical research as well as in clinical settings. The most commonly addressed target structure for imaging angiogenesis is the integrin $\alpha_{v} \beta_{3}$. Here we describe the synthesis and evaluation of $\left[{ }^{18}\right.$ F]FProp-Cys ${ }^{*}$-Arg-Arg-Glu-Thr-Ala-Trp-Ala-Cys ${ }^{*}-\mathrm{OH}$, a radiolabelled peptide designed to selectively target the integrin $\alpha_{5} \beta_{1}$. Conjugation of 4-nitrophenyl-(RS)-2- $\left[{ }^{18} \mathrm{~F}\right]$ fluoropropionate provided $\left[{ }^{18} \mathrm{~F}\right] \mathrm{FProp}-\mathrm{Cys}{ }^{*}$-Arg-Arg-Glu-Thr-Ala-Trp-Ala-Cys ${ }^{*}-\mathrm{OH}$ in high radiochemical purity $(>95 \%)$ and a radiochemical yield of approx. 55\%. In vitro evaluation showed $\alpha_{5} \beta_{1}$ binding affinity in the nanomolar range, whereas affinity to $\alpha_{v} \beta_{3}$ and $\alpha_{I I b} \beta_{3}$ was $>50 \mu \mathrm{M}$. Cell uptake studies using human melanoma M21 ( $\alpha_{v} \beta_{3}-$ positive and $\alpha_{5} \beta_{1}$-negative), human melanoma M21-L ( $\alpha_{v} \beta_{3}$-negative and $\alpha_{5} \beta_{1}$-negative), and human prostate carcinoma DU145 $\left(\alpha_{v} \beta_{3}\right.$-negative and $\alpha_{5} \beta_{1}$-positive) confirmed receptor-specific binding. The radiotracer was stable in human serum and showed low protein binding. Biodistribution studies showed tumour uptake ranging from 2.5 to $3.5 \% \mathrm{ID} / \mathrm{g}$ between 30 and $120 \mathrm{~min}$ post-injection. However, blocking studies and studies using mice bearing $\alpha_{5} \beta_{1}$-negative M21 tumours did not confirm receptorspecific uptake of $\left[{ }^{18} \mathrm{~F}\right]$ FProp-Cys* ${ }^{*}$-Arg-Arg-Glu-Thr-Ala-Trp-Ala-Cys* ${ }^{*} \mathrm{OH}$, although this radiopeptide revealed high affinity and substantial selectivity to $\alpha_{5} \beta_{1}$ in vitro. Further experiments are needed to study the in vivo metabolism of this peptide and to develop improved radiopeptide candidates suitable for PET imaging of $\alpha_{5} \beta_{1}$ expression in vivo.
\end{abstract}

\section{Introduction}

Angiogenesis is a critical step in the formation of cancer. A variety of molecular processes are involved in the formation of new blood vessels out of the preexisting vasculature. Numerous therapeutic strategies in oncology are focused on the inhibition of tumour-induced angiogenesis [1-3]. These include approaches to inhibit VEGF, MMP, or integrin interactions. Thus, there is great interest in techniques which allow noninvasive monitoring of molecular target structures involved in these angiogenic processes [4]. One of the most prominent target structures used for the development of radiopharmaceuticals for imaging angiogenesis yet is the integrin $\alpha_{v} \beta_{3}$ [5]. It has been shown that this integrin is involved in endothelial cell/matrix interactions during tumour-induced formation of new vessels as well as in the mediation of tumour cell migration during invasion and extravasation [6]. A series of studies using a variety of different radiopharmaceuticals have already demonstrated that noninvasive determination of $\alpha_{v} \beta_{3}$ expression is feasible $[5,7]$. This opens the possibility to use single photon emission tomography (SPET) as well as positron emission tomography (PET) techniques to support information for planning and controlling corresponding antiangiogenic therapies. 
In contrast to the data found in a variety of inhibition studies, suggesting a critical role of $\alpha_{v} \beta_{3}$ during angiogenesis and which were the basis for the development of antagonists for this receptor, genetic studies indicate that the integrin $\alpha_{v} \beta_{3}$ is not required for angiogenesis [8]. An explanation for this discrepancy could be found in studies demonstrating that animals lacking $\alpha_{v} \beta_{3}$ develop compensatory changes in VEGF signalling, which permit angiogenesis to occur during embryogenesis [9]. Anyway, genetic ablation of the integrin $\alpha_{5} \beta_{1}$, the major fibronectin-binding integrin, leads to severe vascular abnormalities [10] indicating that this integrin may play an even more important role than the integrin $\alpha_{v} \beta_{3}$ in neovascularisation. Additionally, this integrin is upregulated in tumour blood vessels and plays a role in tumour angiogenesis and tumour growth [11, 12]. Based on these findings, the integrin $\alpha_{5} \beta_{1}$ has become another target structure in the development of radiopharmaceuticals for imaging angiogenesis.

Recently, nonpeptide antagonists for the integrin $\alpha_{5} \beta_{1}$ based on an aza-glycine scaffold with low nanomolar affinity for $\alpha_{5} \beta_{1}$ and up to $10^{4}$-fold higher selectivity when compared with $\alpha_{v} \beta_{3}$ have been developed [13]. Subsequently, the most promising aza-glycine derivative was modified by conjugation with the ${ }^{68} \mathrm{Ga}$-chelator NODAGA [14]. In vitro experiments using a competitive solid phase integrin binding assay have demonstrated receptor specific binding, and in vivo studies with the ${ }^{68} \mathrm{Ga}$-labelled derivative have indicated the feasibility to visualize integrin $\alpha_{5} \beta_{1}$-expression in murine tumour models using small animal PET [14].

Our approach to develop a radiopharmaceutical for the noninvasive determination of integrin $\alpha_{5} \beta_{1}$-expression is based on a disulfide bridged cyclic peptide H-Cys* ${ }^{*}$-Arg-ArgGlu-Thr-Ala-Trp-Ala-Cys* ${ }^{*} \mathrm{OH} \quad$ (H-C* RRETAWAC ${ }^{*}-\mathrm{OH}$; asterisks indicate a disulfide bridge) [15] resulting from a phage display library. It was demonstrated that this compound inhibits the binding of fibronectin to $\alpha_{5} \beta_{1}\left(\mathrm{IC}_{50}\right.$ of $8 \mathrm{nM})$ and the attachment of $\alpha_{5} \beta_{1}$-positive cells. In this work, we describe the synthesis of H-C ${ }^{*}$ RRETAWAC $^{*}-\mathrm{OH}$, its binding affinity for the integrins $\alpha_{v} \beta_{3}, \alpha_{5} \beta_{1}$, and $\alpha_{I I b} \beta_{3}$, and the radiolabelling of the peptide via $\left[{ }^{18} \mathrm{~F}\right]$ fluoropropionic acid. After careful verification of the $\alpha_{5} \beta_{1}$ expression in the cells lines used in this study by FACS analysis, we applied in vitro assays for cell uptake studies and the determination of tracer stability in serum. Finally, the biodistribution of $\left[{ }^{18} \mathrm{~F}\right]$ FProp-CRRETAWAC-OH was studied to assess the applicability of the radiopeptide for imaging of $\alpha_{5} \beta_{1}$ expression in vivo by small animal PET.

\section{Materials and Methods}

All reagents were used as supplied without further purification. 9-Fluorenylmethoxycarbonyl (Fmoc) protected amino acids and tritylchloride polystyrene resins (TCP resin; $\mathrm{H}-$ Cys-2-ClTrt resin) were purchased from Novabiochem of
Merck Millipore Group (Darmstadt, Germany). The coupling reagents 1-hydroxy-7-azabenzotriazole (HOAt) and $O$ (7-azabenzotriazol-1-yl)-1,1,3,3-tetramethyl uroniumhexafluorophosphate (HATU) were purchased from GenScript Corporation (Piscataway, NJ). All other organic reagents were obtained from VWR International GmbH (Darmstadt, Germany) or Sigma-Aldrich Handels GmbH (Buchs, Switzerland). $\left[{ }^{18} \mathrm{~F}\right]$ fluoride was purchased from IASON $\mathrm{GmbH}$ (Graz, Austria) and supplied fixed on a cartridge.

Human melanoma M21 and M21-L cells were a kind gift from D. A. Cheresh, Departments of Immunology and Vascular Biology, The Scripps Research Institute, La Jolla, CA. DU145 human prostate cancer cells were obtained from ATCC (Rockville, MD, USA).

Liquid chromatography mass spectrometry (LC-MS) analysis was carried out using a PepMap C18 column (150 mm $\times 1 \mathrm{~mm}$ ID; $3 \mu \mathrm{m}$ particle size; ICT, Vienna, Austria). The LC system was directly coupled to a Finnigan MAT LCQ ion trap instrument (San Jose, CA) equipped with an electrospray source. Samples were analysed by HPLC (127 Solvent Module, Beckman Instruments, Palo Alto, CA).

NMR spectra were measured with a Bruker AM 360 (Bruker, Karlsruhe, Germany) at $300 \mathrm{~K}$. NMR chemical shifts are reported in ppm relative to trimethylsilane.

The radioactivity of the samples was measured using a 2480 Automatic Gamma Counter Wizard ${ }^{2} 3^{\prime \prime}$ (Perkin Elmer, Vienna, Austria).

\subsection{Synthesis}

2.1.1. Sodium (RS)-2-Fluoropropionate (FProp). The synthesis is based on the procedure described in [16]. Briefly, a mixture of potassium fluoride $\left(55 \mathrm{~g}, 0.95 \mathrm{~mol}\right.$; dried at $150^{\circ} \mathrm{C}$ for $3 \mathrm{~h}$ ), acetamide (50 g; dried for 7 days over phosphor pentoxide), and 2-bromopropionic acid ethyl ester $(33 \mathrm{~g}, 0.18 \mathrm{~mol})$ was stirred for $3 \mathrm{~h}$ at $100^{\circ} \mathrm{C}$. After cooling to room temperature, the mixture was dissolved in water and the organic compounds were extracted with diethyl ether. The ether was removed in vacuo and the product was isolated via vacuum distillation ( $220 \mathrm{mbar}, 72-75^{\circ} \mathrm{C} ; 12 \mathrm{~g}, 0.1 \mathrm{~mol}$; yield $55 \%$ ).

For hydrolysis, the ester was heated under reflux with an equimolar amount of sodium hydroxide in water/methanol $(1: 1)$ for $30 \mathrm{~min}$. Subsequently, the solvent was removed in vacuo. ${ }^{1} \mathrm{H}$ NMR $\left(360 \mathrm{MHz}\right.$, DMSO- $\left.d_{6}\right) \delta 1.32(\mathrm{dd}, J=23.3$, $\left.6.7 \mathrm{~Hz}, 3 \mathrm{H}, \mathrm{CH}_{3}\right), 4.55(\mathrm{dd}, J=52.5,6.7 \mathrm{~Hz}, 1 \mathrm{H}, \mathrm{CFH})$.

2.1.2. $H$ - $C^{*} R R E T A W A C^{*}-O H$. Synthesis of the linear peptide H-CRRETAWAC-OH followed standard solid phase peptide synthesis (SPPS) protocols using Fmoc-protection group strategy and was carried out according to the procedure described in [17]. Disulfide bridge formation was performed in analogy to Schottelius et al. [18]. Briefly, the peptide $(100 \mathrm{mg})$ was suspended in tetrahydrofuran $(15 \mathrm{~mL})$ and ammonium acetate $(5 \mathrm{mM})$ was added until the formation of a clear solution. The solution was adjusted to $\mathrm{pH} 7.0$ by dropwise addition of sodium bicarbonate, and, subsequently, $30 \%$ hydrogen peroxide $(35 \mu \mathrm{L})$ was added. After stirring for $120 \mathrm{~min}$ at room temperature, the solution was removed by 
evaporation, the residue was dissolved in dimethylformamide (DMF), and the product was precipitated by the addition of diethyl ether. The suspension was centrifuged and the precipitate washed with diethyl ether.

The isolation of H-C RRETAWAC* $-\mathrm{OH}$ via semipreparative RP-HPLC was performed using a Gilson 322 HPLC pump with a Gilson UV/VIS-155 detector (Gilson International B.V., Limburg, Germany) and a MultoHigh 100 RP 18 $5 \mu \mathrm{m}, 250 \times 10 \mathrm{~mm}$ column (CS-Chromatographie Service $\mathrm{GmbH}$, Langerwehe, Germany). Flow rate was $5 \mathrm{~mL} / \mathrm{min}$. For preparation, corresponding $\mathrm{CH}_{3} \mathrm{CN} / \mathrm{H}_{2} \mathrm{O} / 0.1 \%$ TFA gradients were used.

Peptide purity and identity were assessed by analytical HPLC (Dionex P680 HPLC pump, Dionex UVD $170 \mathrm{U}$ UV/VIS detector (Dionex, Germering, Germany), Bioscan radiometric detector (Bioscan, Washington, DC), and a Bischoff Nucleosil 120-5 C18 $250 \times 4.6 \mathrm{~mm}$ column (Leonberg, Germany); flow rate $1 \mathrm{~mL} / \mathrm{min}$; UV detection at $220 \mathrm{~nm}$ ) employing the following eluent system: 5-65\% $\mathrm{CH}_{3} \mathrm{CN} / 0.1 \%$ TFA in $30 \mathrm{~min}$, purity: $>95 \%\left(t_{r}: 13.0 \mathrm{~min}\right)$ and ESI-MS: calcd for $\mathrm{C}_{44} \mathrm{H}_{68} \mathrm{~N}_{16} \mathrm{O}_{13} \mathrm{~S}_{2}$ : 1092.6, found: $m / z 1093.5[\mathrm{M}+\mathrm{H}]^{+}$.

2.1.3. FProp-C ${ }^{*}$ RRETAWAC ${ }^{*}-\mathrm{OH}$. For production of FProp-C ${ }^{*}$ RRETAWAC ${ }^{*}-\mathrm{OH}$, microwave assisted (discover microwave oven, CEM Corp., Kamp-Lintfort, Germany) peptide synthesis was carried out in glass tubes loosely sealed with a silicon septum. To avoid overpressure, DMF was used as solvent. After each irradiation step, intermittent cooling of the reaction mixture to a temperature of $-10^{\circ} \mathrm{C}$ was achieved by sufficient agitation in an ethanol-ice bath. Preparative RP-HPLC was performed using Agilent (Waldbronn, Germany) 1100 preparative series (column: Zorbax Eclipse XDB-C8, $21.2 \mathrm{~mm} \times 150 \mathrm{~mm}, 5 \mu \mathrm{m}$ particles, flow rate: $10 \mathrm{~mL} / \mathrm{min}$, detection wavelength: $220 \mathrm{~nm}$ ) and solvent systems as specified below. Purity and identity were assessed by analytical RP-HPLC (Agilent 1100 analytical series, column: Zorbax Eclipse XDB-C8 analytical column, $4.6 \mathrm{~mm} \times 150 \mathrm{~mm}, 5 \mu \mathrm{m}$, flow rate: $0.5 \mathrm{~mL} / \mathrm{min}$, detection wavelength: $220 \mathrm{~nm}$ ) coupled to a Bruker Esquire 2000 mass detector (Bruker Daltonics, Bremen, Germany) equipped with an ESI-trap. The solvent system is specified below. ESI-TOF high mass accuracy and resolution experiments were performed on a BRUKER maXis MS (Bruker Daltonics, Bremen) in the laboratories of the Chair of Organic Chemistry (Professor Dr. Rik Tykwinski), Department of Pharmacy and Chemistry, Friedrich-Alexander University Erlangen-Nürnberg (FAU).

The peptide synthesis was achieved starting from $\mathrm{H}-$ Cys-2-ClTrt resin (100 mg, loading $0.56 \mathrm{mmol} / \mathrm{g})$. The amino acids were incorporated as their commercially available derivatives in the following order: Fmoc-Ala-OH, Fmoc$\operatorname{Trp}(\mathrm{Boc})-\mathrm{OH}$, Fmoc-Thr( $t \mathrm{Bu})-\mathrm{OH}$, Fmoc-Glu(OtBu)-OH, and Fmoc-Arg(Pbf)-OH. Elongation of the peptide chain was done by repetitive cycles of Fmoc-deprotection applying $20 \%$ piperidine in DMF (microwave irradiation: $5 \times$ $5 \mathrm{~s}, 100 \mathrm{~W}$ ), followed by 5 washing steps with DMF and subsequent peptide coupling using the following conditions: amino acid/PyBOP/diisopropylethylamine $\mathrm{HOBt}$
(5 eq/5 eq/5 eq/7.5 eq). Exception was made for Fmoc$\operatorname{Trp}$ (Boc)-OH, which (5 eq) was coupled for a second time with HATU/DIPEA ( $5 \mathrm{eq} / 5 \mathrm{eq})$. The last cysteine residue was introduced as the pentafluorophenyl ester (FmocCys(Trt)-OPfp, 5 eq) without addition of base. Coupling of sodium $(R S)$-2-fluoropropionate (5 eq) was carried out using HATU/DIPEA ( $5 \mathrm{eq} / 7 \mathrm{eq}$ ) activation. All building blocks and reagents were dissolved in a minimum amount of DMF and microwave irradiation was performed $15 \times 10 \mathrm{~s}$ employing $50 \mathrm{~W}$. After the last acylation step, the resin was 10 times rinsed with $\mathrm{CH}_{2} \mathrm{Cl}_{2}$ and dried in vacuo.

The cleavage of the peptide from the resin was performed using a mixture of TFA/phenol/ $\mathrm{H}_{2} \mathrm{O} /$ thioanisole/EDT/trisopropylsilane $(80.5 / 5 / 5 / 2.5 / 2)$ for $2 \mathrm{~h}$. After evaporation of the solvent and precipitation in $t$-butylmethylether, the crude peptide was washed 3 times with $t$-butylmethylether and dissolved in acetic acid $(6 \mathrm{~mL})$. Then the solution was diluted with water $(800 \mathrm{~mL})$ and adjusted to $\mathrm{pH} 8$ employing $25 \%$ $\mathrm{NH}_{3}$ and vigorous stirring was performed in order to ensure saturation with air for the oxidative cyclization of the cysteine thiol residues. After $2 \mathrm{~d}$, the mixture was lyophilised and purified using preparative RP-HPLC (eluent: $\mathrm{CH}_{3} \mathrm{CN}$ (A); $0.1 \% \mathrm{HCO}_{2} \mathrm{H}$ in $\mathrm{H}_{2} \mathrm{O}(\mathrm{B})$ applying a linear gradient $10 \%-18 \%$ (A) in $26 \mathrm{~min}$ ).

For FProp-C* $\mathrm{RRETAWAC}^{*}-\mathrm{OH}$, two epimers were found ( $t_{r}$ epimer 1: $17.0 \mathrm{~min}$, and epimer 2: $\left.18.4 \mathrm{~min}\right)$. In order to obtain a pure fraction of epimer 2, a second HPLCseparation had to be performed. Peptide purity and identity were assessed by analytical HPLC employing the following eluent system: $3-30 \% \mathrm{CH}_{3} \mathrm{CN}$ in $97-70 \% \mathrm{H}_{2} \mathrm{O}+0.1 \%$ $\mathrm{HCO}_{2} \mathrm{H}$ in $26 \mathrm{~min}$, epimer 1: purity: $>99 \%\left(t_{r}: 20.2 \mathrm{~min}\right)$, epimer 2: purity: $>99 \%\left(t_{r}: 21.2 \mathrm{~min}\right)$; ESI-ToF-MS: $[\mathrm{M}+\mathrm{H}]^{+}$, calculated for $\mathrm{C}_{47} \mathrm{H}_{72} \mathrm{FN}_{16} \mathrm{O}_{14} \mathrm{~S}_{2}$ : 1167.4839, found: 1167.4831 .

2.1.4. Ala-Scan-Peptides. Peptides modified with alanine on the different positions and used for the Ala-scan (see Table 1) have been purchased from Biosynthan (Berlin, Germany). These peptides were analysed by MALDI-TOF and HPLC. Supplied peptides were $>95 \%$ pure.

2.2. ${ }^{18}$ F]labelling of $H-C^{*} R R E T A W A C^{*}-O H$. For labelling $\mathrm{H}-\mathrm{C}^{*}$ RRETAWAC ${ }^{*}-\mathrm{OH},(R S)-2-\left[{ }^{18} \mathrm{~F}\right]$ fluoropropionate (FProp) was used as a prosthetic group. labelling of the compound was carried out in a semiautomated system, which has been established at the Department of Nuclear Medicine in Innsbruck. Synthesis of the prosthetic group was carried out as described previously [17] and followed the protocols from Guhlke et al. [19]. For the final conjugation step, 4-nitrophenyl-(RS)-2-[ $\left.{ }^{18} \mathrm{~F}\right]$ fluoropropionate (100-200 MBq) was coated in a plastic vial and the corresponding peptide $(0.5-1.0 \mathrm{mg})$, dissolved in anhydrous DMSO $(200 \mu \mathrm{L})$, was added and heated in the presence of 3 eq. KOBt (potassium salt of 1-hydroxybenzotriazole (HOBt)) for $10 \mathrm{~min}$ at $70^{\circ} \mathrm{C}$. After reaction, the mixture was transferred to a syringe and the vial was washed with DMSO $(200 \mu \mathrm{L})$ and water $(200 \mu \mathrm{L})$. Combined solvents were injected onto semipreparative HPLC (Gynkotech 480 High Precision Pump, a Gynkotech SP6V UV detector (Germering, Germany), and a 
TABLE 1: List of the peptides synthesized (asterisks indicate disulfide bridge).

\begin{tabular}{|c|c|}
\hline Lead stucture & H-C ${ }^{*}$ RRETAWAC $^{*}-\mathrm{OH}$ \\
\hline Reference compound & FProp-C*RRETAWAC* $-\mathrm{OH}$ \\
\hline \multirow[t]{3}{*}{ Labelling precursor } & H-C*RRETAWAC* -OH \\
\hline & H-C ${ }^{*}$ ARETAWAC* $-\mathrm{OH}$ \\
\hline & H-C* RAETAWAC* ${ }^{*} \mathrm{OH}$ \\
\hline \multirow[t]{3}{*}{ Ala-scan } & H-C*RRATAWAC* ${ }^{*} \mathrm{OH}$ \\
\hline & H-C* RREAAWAC* ${ }^{*}-\mathrm{OH}$ \\
\hline & H-C*RRETAAAC* $-\mathrm{OH}$ \\
\hline Labelled compound & {$\left[{ }^{18} \mathrm{~F}\right]$ FProp-C ${ }^{*}$ RRETAWAC ${ }^{*}-\mathrm{OH}$} \\
\hline
\end{tabular}

Bioscan radiometric detector with a Multo-High 100 RP 18$5 \mu \mathrm{m}$ column $(250 \times 10 \mathrm{~mm}$; CS-Chromatography, Langerwehe, Germany) using the following gradient: $10-50 \%$ $\mathrm{CH}_{3} \mathrm{CN} /$ water $/ 0.1 \% \mathrm{TFA}$ in $30 \mathrm{~min}$; flow rate $5 \mathrm{~mL} / \mathrm{min}$ ), and the corresponding radio peak was collected. The HPLC solvent was removed by evaporation and the title compound $\left[{ }^{18} \mathrm{~F}\right]$ FProp-C $\mathrm{C}^{*}$ RRETAWAC ${ }^{*}-\mathrm{OH}$ was reconstituted in PBS ( $\mathrm{pH}$ 7.4) for subsequent in vitro and in vivo experiments.

\subsection{In Vitro Characterisation}

2.3.1. Partition Coefficient. $\left[{ }^{18} \mathrm{~F}\right]$ FProp-C $\mathrm{C}^{*} \mathrm{RRETAWAC}^{*}-\mathrm{OH}$ (approx. $1 \mathrm{kBq})$ in PBS $(250 \mu \mathrm{L}, \mathrm{pH} 7.4)$ was added to octanol $(250 \mu \mathrm{L})$ and the mixture was vigorously vortexed for $15 \mathrm{~min}$. Subsequently, aliquots of the aqueous and the octanol layer were collected (each $75 \mu \mathrm{L}$ ) and measured in the gamma counter, and $\log \mathrm{D}$ values were calculated $(n=5)$.

2.3.2. Protein Binding Assay. The protein binding studies were carried out by incubating $\left[{ }^{18} \mathrm{~F}\right]$ FProp-C $\mathrm{C}^{*}$ RRETAWAC ${ }^{*}$ $\mathrm{OH}(1 \mathrm{MBq} / \mathrm{mL})$ in fresh human serum at $37^{\circ} \mathrm{C}$ for different time points $(30,60$, and $120 \mathrm{~min})$. After incubation, the solution was passed through a spin column (MicroSpin G-50 columns; GE Healthcare, Buckinghamshire, United Kingdom). Protein binding was determined by measuring the activity fixed on the column and the activity in the eluate in the gamma counter. As control $\left[{ }^{18} \mathrm{~F}\right]$ FProp-C $\mathrm{C}^{*}$ RRETAWAC* $\mathrm{OH}$ was incubated at the same concentration for $60 \mathrm{~min}$ in PBS instead of serum.

2.3.3. Stability in Human Serum. For stability studies, $\left[{ }^{18} \mathrm{~F}\right]$ FProp-C ${ }^{*}$ RRETAWAC ${ }^{*}-\mathrm{OH}$ (approx. $2 \mathrm{MBq} / \mathrm{mL}$ ) was incubated in human serum for 30,60 , and $120 \mathrm{~min}$ at $37^{\circ} \mathrm{C}$. At each time point, aliquots of $100 \mu \mathrm{L}$ were taken and proteins were precipitated using $150 \mu \mathrm{L}$ acetonitrile. The suspension was treated for $5 \mathrm{~min}$ with ultrasound and subsequently centrifuged. The supernatant was diluted with water and analysed by HPLC.

2.3.4. Determination of $K_{i}$-Values Using Isolated Receptor Binding Assays. The receptor binding assay was performed following the procedure described previously [20]. In brief, commercially available purified $\alpha_{v} \beta_{3}, \alpha_{5} \beta_{1}$, or $\alpha_{I I b} \beta_{3}$ (Triton X-100 formulation, Chemicon, Millipore) was diluted in coating buffer (25 mM Tris- $\mathrm{HCl}, 150 \mathrm{mM} \mathrm{NaCl}, 1 \mathrm{mM} \mathrm{CaCl}_{2}$, $0.5 \mathrm{mM} \mathrm{MgCl} 2,1 \mathrm{mM} \mathrm{MnCl}, \mathrm{pH} \mathrm{7.4)}$, and an aliquot of $100 \mu \mathrm{L} /$ well, corresponding to $25 \mathrm{ng} /$ well $\alpha_{v} \beta_{3}, 100 \mathrm{ng} /$ well $\alpha_{5} \beta_{1}$, or $50 \mathrm{ng} /$ well $\alpha_{\text {IIb }} \beta_{3}$, was added to a 96 -well microtiter plate (Maxisorb, Nunc, Wiesbaden, Germany) and incubated at $4^{\circ} \mathrm{C}$ overnight. The cells were incubated for two hours with blocking buffer $(200 \mu \mathrm{L}$, coating buffer containing $1 \%$ $(\mathrm{w} / \mathrm{v})$ bovine serum albumin (BSA)) at room temperature. After washing twice with binding buffer (coating buffer with $0.1 \%(\mathrm{w} / \mathrm{v}) \mathrm{BSA})$ the cells were incubated in the presence of the competing ligand $(90 \mu \mathrm{L}, 0.5 \mathrm{pM}$ to $500 \mathrm{nM}$ echistatin; $0.05 \mathrm{nM}$ to $50 \mu \mathrm{M}$ peptide in binding buffer) with $\left[{ }^{125} \mathrm{I}\right]$ echistatin $(0.37 \mathrm{kBq} /$ well, $10 \mu \mathrm{L}, 0.05 \mathrm{nM}$; PerkinElmer, Germany) for $3 \mathrm{~h}$. Afterwards, the cells were washed three times with binding buffer, and bound $\left[{ }^{125} \mathrm{I}\right]$ echistatin was solubilised with warm $\mathrm{NaOH}(2 \mathrm{M})$. The radioactivity in the resulting samples was measured by a $\gamma$-counter. Each data point represents the mean from three cells. All measurements were repeated at least once. $K_{i}$ values were calculated using the software program GraphPad PRISM (GraphPad Software Inc., CA, USA).

\subsubsection{Characterisation of the Murine Tumour Models}

(1) Flow Cytometry. Cells were washed with cold PBS and incubated with mouse anti-human integrin $\alpha_{5} \beta_{1}$ (MAB 1999, Millipore, 1:75), mouse anti-human integrin $\alpha_{v} \beta_{3}$ (MAB1976, clone LM609, Millipore, 1:75), or a negative control IgG (DAKO) for 30 minutes at $4^{\circ} \mathrm{C}$, followed by incubation with a FITC-labelled goat anti-mouse secondary antibody (1:400, $2.5 \mu \mathrm{L}$ in $1 \mathrm{~mL}$ DAKO). After careful washing to remove unbound antibodies, samples were analysed on a FACSCalibur flow cytometer (Becton Dickinson, USA). The analysis was performed by Cell Quest software version 4.0.1 (Becton Dickinson, USA).

(2) Immunofluorescent Staining. Three mice with DU145 tumour xenografts induced as described below were sacrificed and tumour tissue was removed and frozen in liquid nitrogen. Frozen tissue sections were fixed with acetone for 10 minutes, followed by blocking with PBS $+10 \%$ goat serum for 20 minutes at room temperature. Then, slides were incubated with a mouse monoclonal antibody against $\alpha_{5} \beta_{1}$ integrin (MAB 1999, Millipore, 1:50) for 1 hour at $37^{\circ} \mathrm{C}$. Negative control sections were stained with an unspecific isotype control (DAKO). After washing, samples were incubated with an Alexa Fluor 555 goat anti-mouse IgG (Molecular Probes, $1: 800$ ) for 30 minutes at $37^{\circ} \mathrm{C}$. After washing, the slides were covered with Vectashield mounting medium (Vector Labs) with DAPI ( $4^{\prime}, 6$-diamidino-2-phenylindole) and analysed with an Axio Imager Z2 microscope (Zeiss, Vienna) equipped 
with a Pixelink PL-B622-CU camera (Canimpex Enterprises Ltd., Halifax, NS, Canada).

2.3.6. Cell Uptake Studies. M21 $\left(\alpha_{v} \beta_{3}\right.$-positive and $\alpha_{5} \beta_{1}$ negative), DU154 ( $\alpha_{v} \beta_{3}$-negative and $\alpha_{5} \beta_{1}$-positive), and M21L (both receptors negative) cells were maintained in Gibco RPMI 1640 (Life Technologies, Carlsbad, CA) containing $1 \%$ glutamine, $10 \%(\mathrm{v} / \mathrm{v})$ fetal calf serum (FCS), and $1 \%$ penicillin/streptomycin/glutamine and grown in tissue culture flasks (Cellstar; Greiner Bio-One, Kremsmuenster, Austria) at $37^{\circ} \mathrm{C}$ in a humidified atmosphere of $5 \% \mathrm{CO}_{2}(\mathrm{v} / \mathrm{v})$. For cell uptake studies, cells were trypsinised, washed twice with binding buffer (10 mM HEPES ( $\mathrm{pH} 7.4$ ), $150 \mathrm{mM} \mathrm{NaCl}$, $2 \mathrm{mM} \mathrm{MnCl}_{2}, 0.1 \% \mathrm{BSA}$ ), and aliquots of $0.9 \mathrm{~mL}$ containing 2 $\times 10^{6}$ cells were transferred to Eppendorf tubes. After addition of $50 \mu \mathrm{L}$ radiotracer $(>100,000 \mathrm{cpm})$, cells were incubated at $37^{\circ} \mathrm{C}$ for $120 \mathrm{~min}$ in triplicate with either $50 \mu \mathrm{L}$ PBS with $0.5 \%$ BSA (unblocked) or $50 \mu \mathrm{L}$ of $50 \mu \mathrm{M} \mathrm{H}-\mathrm{C}^{*}$ RRETAWAC $^{*}-\mathrm{OH}$ in PBS/0.5\% BSA (blocked), respectively.

Incubation was stopped by centrifugation $(2 \mathrm{~min}$, $1000 \mathrm{rpm}$ ); medium was removed and cells were washed twice with $1 \mathrm{~mL}$ ice-cold binding buffer. Subsequently, cells were incubated in acid wash buffer $(20 \mathrm{mM}$ acetate buffer $\mathrm{pH}$ 4.5) for 10 minutes at $37^{\circ} \mathrm{C}$. The supernatant was collected (membrane bound radioligand fraction) and the cells were washed with acid wash buffer. Cells were lysed by treatment in $1 \mathrm{~N} \mathrm{NaOH}$ and receptor bound radioactivity was collected (internalised radioligand fraction). Protein content in the $\mathrm{NaOH}$ fraction was determined using spectrophotometric determination with Bradford reagent (Sigma Aldrich, Vienna, Austria). Internalised radioactivity was expressed as percentage of total activity per mg protein.

2.4. In Vivo Characterisation. All animal experiments were conducted in compliance with the Austrian animal protection laws and with the approval of the Austrian Ministry of Science (BMBWK-66.011/0066-BrGT/2006). Animal studies were performed using BALB/c nude mice (Charles River Laboratories, Sulzfeld, Germany). For the induction of tumour xenografts, human prostate cancer DU145 cells $\left(\alpha_{v} \beta_{3}\right.$ negative and $\alpha_{5} \beta_{1}$ positive) as well as human melanoma M21 cells ( $\alpha_{v} \beta_{3}$ positive and $\alpha_{5} \beta_{1}$ negative) were injected subcutaneously at a concentration of $5 \times 10^{6}$ cells per mouse and allowed to grow until tumours of $0.3-0.6 \mathrm{~cm}^{3}$ were visible.

2.4.1. Biodistribution Studies. A group of 10 mice bearing the DU145 tumour xenograft was injected with $\left[{ }^{18} \mathrm{~F}\right]$ FProp$\mathrm{C}^{*}$ RRETAWAC ${ }^{*}-\mathrm{OH}$ (approx. $0.5 \mathrm{MBq}$ per animal in $150 \mu \mathrm{L}$ $\mathrm{PBS}$ pH 7,4) into a lateral tail vein. The animals were sacrificed by cervical dislocation 30,60 , and $120 \mathrm{~min}$ after injection. Organs (heart, stomach, lung, spleen, liver, pancreas, kidneys, and intestine), tissues (blood, muscle, and femur), and tumours were removed and weighed. Activity concentration in the samples was measured in the gamma counter. Results were expressed as percentage of injected dose per gram of tissue (\% ID/g).

For determination of receptor selectivity of the tracer uptake distribution in mice bearing the human melanoma,
M21 tumour xenograft as well as blocking with different amounts of $\mathrm{H}_{-} \mathrm{C}^{*} \mathrm{RRETAWAC}^{*} \mathrm{OH}(200 \mu \mathrm{g}$ and $300 \mu \mathrm{g})$ was studied. For each group, 4 animals were injected with $\left[{ }^{18}\right.$ F]FProp-C ${ }^{*}$ RRETAWAC ${ }^{*}$-OH (approx. $0.5 \mathrm{MBq}$ per animal in $150 \mu \mathrm{L}$ PBS $\mathrm{pH}$ 7.4) intravenously into the lateral tail vein. The animals were sacrificed by cervical dislocation 60 min after injection. Further processing was similar as described above.

\section{Results}

3.1. Peptide Synthesis and Radiolabelling. The peptides were assembled on solid support using Fmoc-protocols (a list of all peptides used in the study is found in Table 1). Disulfide-bridge formation of the CRRETAWAC-peptides was carried out using either hydrogen peroxide or oxygen. All peptides have been synthesised in purity higher than $95 \%$. For the reference compound, conjugation of the racemic 2fluoropropionate resulted in the formation of two epimeres, which could be separated by HPLC and tested for binding affinity separately (see below).

Peptide labelling was carried out using 4-nitrophenyl(RS)-2- $\left[{ }^{18} \mathrm{~F}\right]$ fluoropropionate which was synthesised as described previously [17]. For the final conjugation step, the prosthetic group was coated in a plastic vial. It is of utmost importance to avoid any trace of water in this reaction. For the acylation, the peptide, dissolved in anhydrous DMSO, was added and heated for $10 \mathrm{~min}$ at $70^{\circ} \mathrm{C}$. This procedure allowed radiolabelling of $\mathrm{H}_{-} \mathrm{C}^{*} \mathrm{RRETAWAC}^{*}-\mathrm{OH}$ with radiochemical yields of approx. $2.3 \%$. To improve the radiochemical yield, 3 eq. KOBt was added to the peptide. This optimised procedure allowed $\left[{ }^{18} \mathrm{~F}\right]$ labelling of $\mathrm{H}$ $C^{*}$ RRETAWAC $^{*}-\mathrm{OH}$ with radiochemical yields of approx. $55 \%$. After final HPLC preparation, the radiochemical purity was in general $>95 \%$. Under the used HPLC conditions, no epimeres could be identified/separated for the radiolabelled derivatives.

\subsection{In Vitro and In Vivo Characterisation}

3.2.1. Partition Coefficient, Protein Binding, Serum Stability. Octanol/buffer partition coefficient $(\log \mathrm{D})$ of $\left[{ }^{18} \mathrm{~F}\right]$ FProp$\mathrm{C}^{*} \mathrm{RRETAWAC}^{*}-\mathrm{OH}$ was determined to be -1.9 . Protein bound activity of $\left[{ }^{18} \mathrm{~F}\right]$ FProp- $\mathrm{C}^{*}$ RRETAWAC $^{*}-\mathrm{OH}$ in human serum increased over time but remained below $6 \%$ of the total incubated activity after $2 \mathrm{~h}$ incubation (Figure 1 ). The stability of $\left[{ }^{18} \mathrm{~F}\right]$ FProp-C ${ }^{*}$ RRETAWAC ${ }^{*}-\mathrm{OH}$ in human serum in vitro was excellently high (Figure 2). Over $90 \%$ intact tracer was found at all time points during the observation period of $120 \mathrm{~min}$.

3.2.2. Expression Pattern of the Different Cell Lines. Human prostate cancer (DU145) and human melanoma (M21 and M21-L) cells were analysed regarding $\alpha_{v} \beta_{3}$ and $\alpha_{5} \beta_{1}$ integrin expression (Figure 3; figures show for each integrin and cell line one representative FACS analysis as well as mean values of the median). FACS analysis revealed high $\alpha_{5} \beta_{1}$ and low $\alpha_{v} \beta_{3}$ expression for the DU145 cell line. M21 cells showed 


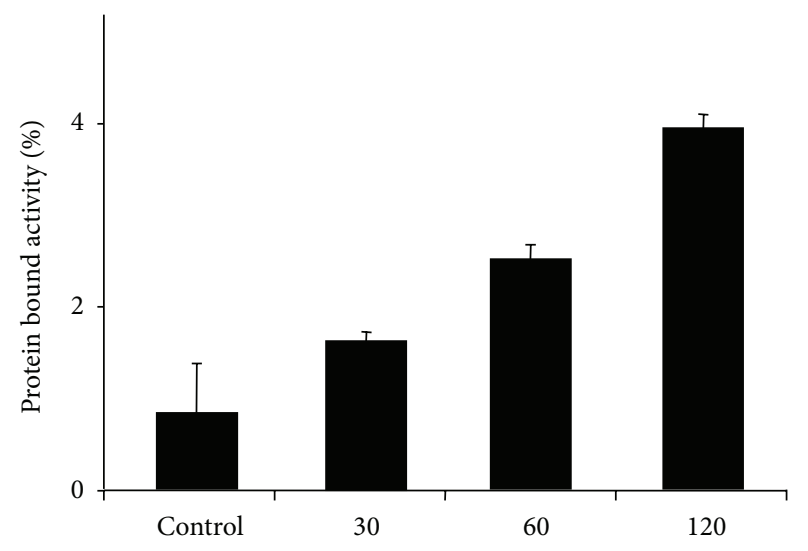

FIGURE 1: Amount of protein fraction after incubation of $\left[{ }^{18} \mathrm{~F}\right]$ FProp-C ${ }^{*}$ RRETAWAC ${ }^{*}-\mathrm{OH}$ in human serum for 30,60 , and $120 \mathrm{~min}$ at $37^{\circ} \mathrm{C}$. As control, the radiopharmaceutical was incubated in PBS for $60 \mathrm{~min} 37^{\circ} \mathrm{C}$.

a reversed expression pattern. These cells revealed high $\alpha_{v} \beta_{3}$ and low $\alpha_{5} \beta_{1}$ expression. M21-L cells showed not only low $\alpha_{v} \beta_{3}$ but also low $\alpha_{5} \beta_{1}$ expression. Therefore, this cell line was used as negative control cell line for both receptor types.

DU145 tumour tissue sections were stained with a monoclonal $\alpha_{5} \beta_{1}$ anti-antibody and costained with DAPI allowing identification of the cell nucleus. Fluorescence microscopic analysis of the tumour tissue sections confirmed expression of $\alpha_{5} \beta_{1}$ on the murine DU145 tumour model used (Figure 4).

3.2.3. Integrin Binding Data and Cell Uptake Studies. The binding affinities were determined using isolated receptor binding assays where the different integrins $\left(\alpha_{5} \beta_{1}, \alpha_{v} \beta_{3}\right.$, and $\left.\alpha_{I I b} \beta_{3}\right)$ were immobilised and $\left.{ }^{[25} \mathrm{I}\right]$ echistatin was replaced by increasing amounts of the different peptides tested. H-C*RRETAWAC* $-\mathrm{OH}$ and the two isomers of FProp$\mathrm{C}^{*}$ RRETAWAC ${ }^{*}-\mathrm{OH}$ were able to fully suppress the binding of $\left.{ }^{125} \mathrm{I}\right]$ echistatin to the immobilised integrin $\alpha_{5} \beta_{1}$ and the binding kinetics followed a classic sigmoid path (corresponding $K_{i}$ values are found in Table 2). Introduction of the (RS)-2-fluoropropionic acid at the $\mathrm{N}$-terminus of the peptide reduced the binding affinity by a factor of approx. 10. The different isomers, which were separated via HPLC, did not show significant differences in the binding to integrin $\alpha_{5} \beta_{1}$. Binding affinity to integrins $\alpha_{v} \beta_{3}$ and $\alpha_{I I b} \beta_{3}$ was found to be above $50 \mu \mathrm{M}$ indicating the $\alpha_{5} \beta_{1}$-preferring selectivity of the compound.

In a subsequent test series of assays, the influence of the different amino acids on the binding affinity to integrin $\alpha_{5} \beta_{1}$ has been determined. Therefore, an Ala-scan was performed and the resulting 5 peptides were compared in their binding capability with the lead structure H-Cys ${ }^{1}{ }^{*}-\mathrm{Arg}^{2}-\mathrm{Arg}^{3}-\mathrm{Glu}^{4}-$ $\mathrm{Thr}^{5}-\mathrm{Ala}^{6}-\mathrm{Trp}^{7}-\mathrm{Ala}^{8}-\mathrm{Cys}{ }^{9 *}-\mathrm{OH}$. Replacement of $\mathrm{Arg}^{3}$ has only minor influence on the binding of the peptide to the integrin $\alpha_{5} \beta_{1}$. In contrast, replacement of $\mathrm{Arg}^{2}, \mathrm{Glu}^{4}, \mathrm{Thr}^{5}$, or $\operatorname{Trp}^{7}$ by Ala resulted in a complete loss of the binding affinity indicating that these amino acids are of great importance for binding to integrin $\alpha_{5} \beta_{1}$.
The corresponding cell uptake studies where cells were incubated for $90 \mathrm{~min}$ at $37^{\circ} \mathrm{C}$ with $\left[{ }^{18} \mathrm{~F}\right]$ FProp$\mathrm{C}^{*}$ RRETAWAC $^{*}-\mathrm{OH}$ with or without an excess of the lead structure $\mathrm{H}-\mathrm{C}^{*}$ RRETAWAC ${ }^{*}-\mathrm{OH}$ showed specific binding and internalisation for the $\alpha_{5} \beta_{1}$-expressing DU145 but not for the $\alpha_{v} \beta_{3}$-expressing M21 cells. In addition, no specific uptake was found in M21-L cells which express neither $\alpha_{5} \beta_{1}$ nor $\alpha_{v} \beta_{3}$ (Figure 5).

3.2.4. Biodistribution and Blocking Studies. Biodistribution and blocking studies were carried out using BALB/c nude mice bearing DU145 tumour xenografts. For additional studies concerning receptor selective tumour uptake, nude mice bearing M21 tumour xenografts were used.

Distribution of $\left[{ }^{18} \mathrm{~F}\right]$ FProp-C ${ }^{*}$ RRETAWAC ${ }^{*}-\mathrm{OH}$ was determined 30, 60, and 120 min after tracer injection. Data showed highest tracer concentration in the $\alpha_{5} \beta_{1}$ positive DU145 tumour tissue for all time points studied with the maximum of $3.4 \% \mathrm{ID} / \mathrm{g}$ at $60 \mathrm{~min}$ p.i. (Figure 6). Nevertheless, activity accumulation in blood was only slightly lower and ranged from $2.4 \% \mathrm{ID} / \mathrm{g} 30 \mathrm{~min}$ p.i. to $3.0 \% \mathrm{ID} / \mathrm{g} 120 \mathrm{~min}$ p.i. All other organs showed tracer concentration between 1.0\% ID/g (muscle $30 \mathrm{~min} \mathrm{p.i.)} \mathrm{and} \mathrm{2.5 \%} \mathrm{(kidneys} 30 \mathrm{~min}$ p.i.). The kidney was the only organ for which marginal clearance of the tracer was observed. For all other organs including blood there was a constant or even increasing activity concentration found between 30 and 120 min after tracer injection.

The initial blocking experiment where $200 \mu \mathrm{g}$ of $\mathrm{H}$ $\mathrm{C}^{*} \mathrm{RRETAWAC}^{*}-\mathrm{OH}$ per mouse was coinjected with the tracer showed only low reduction of tracer accumulation in the tumour (Figure 7). However, for all other organs, no reduction or even higher radioactivity concentration was found. To verify if the concentration of the blocking compound was sufficient, an additional experiment using $300 \mu \mathrm{g} \mathrm{H}-\mathrm{C}^{*} \mathrm{RRETAWAC}^{*}$-OH per mouse was carried out. Moreover, uptake in mice bearing M21 tumour xenografts was studied. This tumour does not express the $\alpha_{5} \beta_{1}$ integrin (see Figure 3) and was used as a negative control. However, neither the "high dose" blocking nor the experiment with the M21 tumour xenograft bearing mice showed any significant reduction in tracer uptake in the tumour indicating that, if at all, accumulation is only slightly receptor mediated.

\section{Discussion}

Noninvasive imaging of molecular processes during angiogenesis is of utmost importance for both preclinical settings where it may allow new insights in the complex mechanisms as well as for patient care where it may allow more specific planning and controlling of antiangiogenic therapies. One promising target structure family involved in the angiogenic process is the integrins. Until now, most of the studies focused on the integrin $\alpha_{v} \beta_{3}$. However, other integrins recently came into the focus of interest, including integrin $\alpha_{5} \beta_{1}$ [21], which seems to play an even more important role in the angiogenic process than $\alpha_{v} \beta_{3}$. Based on the nine amino acid sequence $\mathrm{H}$ $\mathrm{C}^{*} \mathrm{RRETAWAC}^{*}-\mathrm{OH}$ that has been found by phage display techniques [15] and which demonstrated high affinity for the 

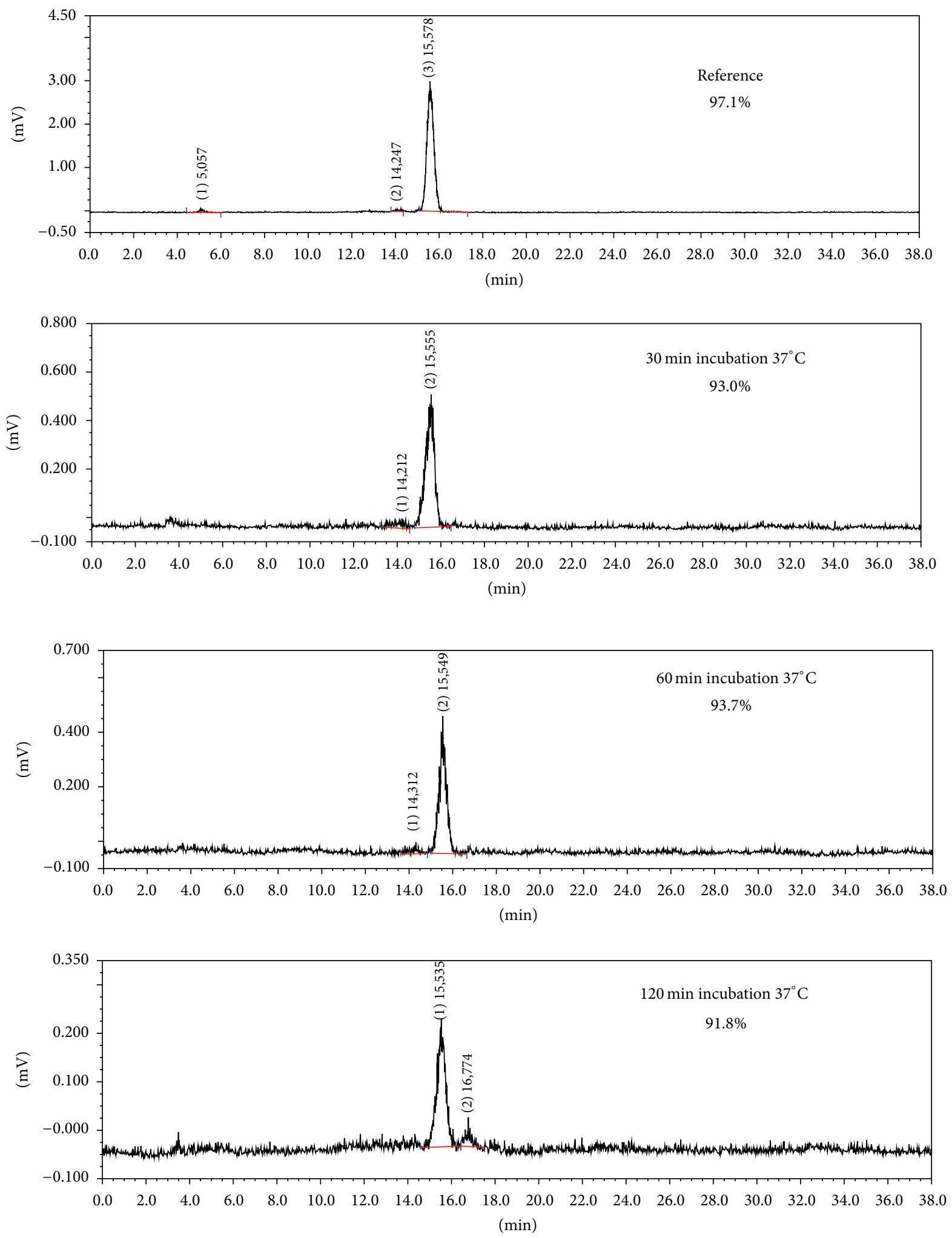

Figure 2: Serum stability of $\left[{ }^{18}\right.$ F]FProp-C ${ }^{*}$ RRETAWAC ${ }^{*}-\mathrm{OH}$. 


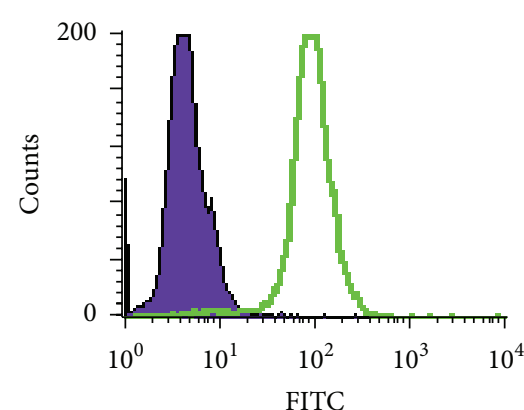

(A)

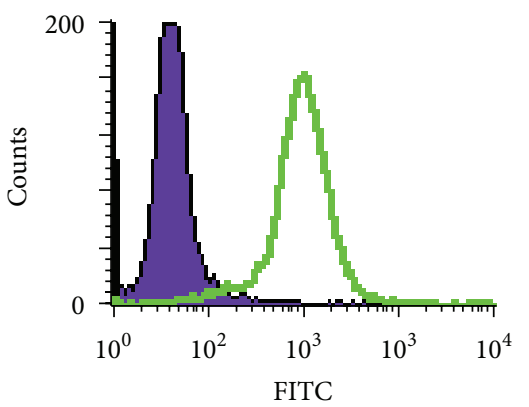

(D)

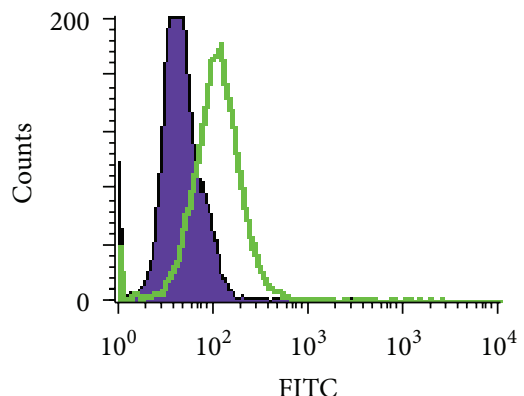

(B)

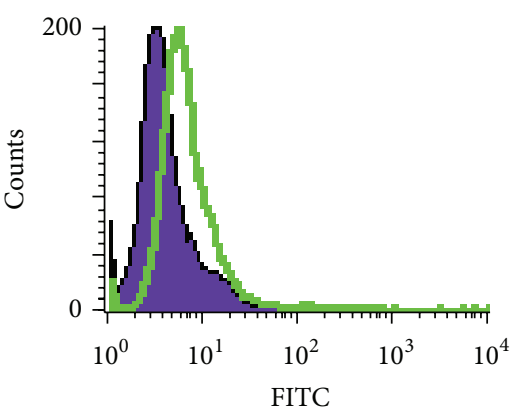

(E)

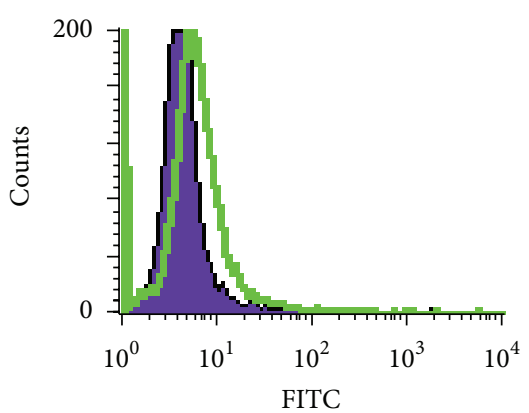

(C)

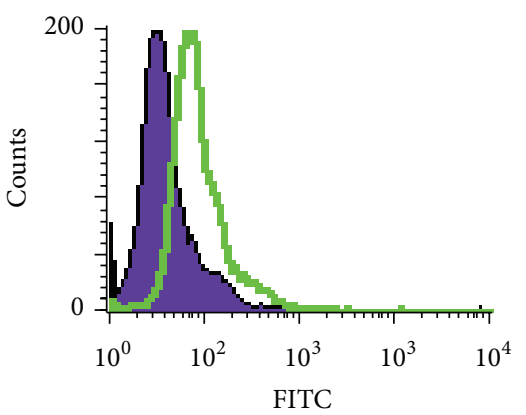

(F)

(a)

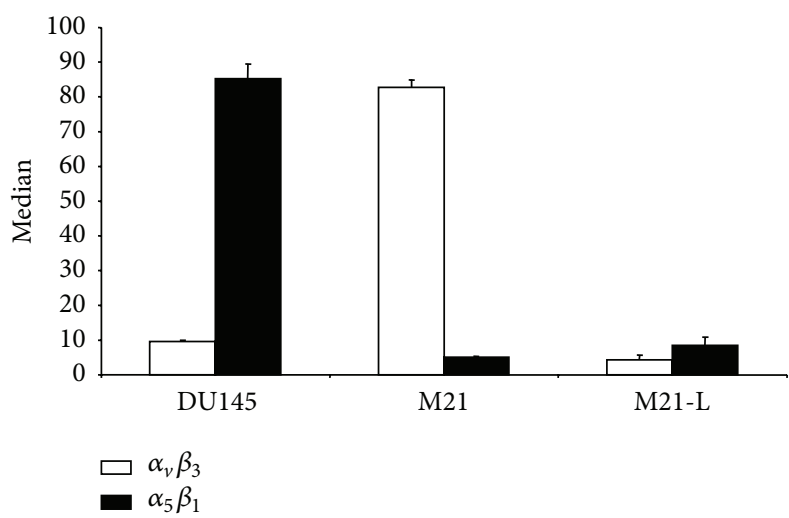

(b)

FigURE 3: FACS analysis of human prostate carcinoma DU145 as well as human melanoma M21 and M21-L cells. (a): (A) + (B): DU145; (C) + (D): M21; (E) + (F): M21-L; (A), (C), (E): IgG-isotype overlay with $\alpha_{5} \beta_{1}$; (B), (D), (F): IgG-isotype overlay with $\alpha_{v} \beta_{3}$; (b): presentation of the median of the different analysis.

integrin $\alpha_{5} \beta_{1}$ in different in vitro assays, we aimed at the synthesis and the in vitro and in vivo characterisation of the $\left[{ }^{18} \mathrm{~F}\right]$ labelled derivative $\left[{ }^{18} \mathrm{~F}\right]$ FProp-C ${ }^{*}$ RRETAWAC ${ }^{*}-\mathrm{OH}$ to study its applicability as a $\alpha_{5} \beta_{1}$-selective PET imaging ligand.

labelling was carried out in analogy to $\left[{ }^{18} \mathrm{~F}\right]$ GalactoRGD [17] using 4-nitrophenyl-(RS)-2-[ $\left[{ }^{18} \mathrm{~F}\right]$ fluoropropionate. The initial synthesis resulted in low yields; however, after introduction of the potassium salt of 1-hydroxybenzotriazole $(\mathrm{KOBt})$, which is thought to form an activated ester as reactive intermediate, the yield of the final conjugation step could be increased from $2.3 \%$ to approx. 55\%. Thus, the peptide could be successfully labelled using this approach. The labelling yields are sufficient even for the use in clinical settings, and this is why this labelling strategy was used for the evaluation of this class of tracer. Anyway, due to the comparably complex labelling strategy, after successful evaluation, alternative labelling strategies have to be developed for an easier translation into a potential clinical routine use.

The binding affinity and receptor selectivity of the modified peptide were controlled using the corresponding isolated immobilised integrins. The selectivity of $\left[{ }^{18} \mathrm{~F}\right]$ FProp$\mathrm{C}^{*} \mathrm{RRETAWAC}^{*}-\mathrm{OH}$ was comparable to that of the lead 


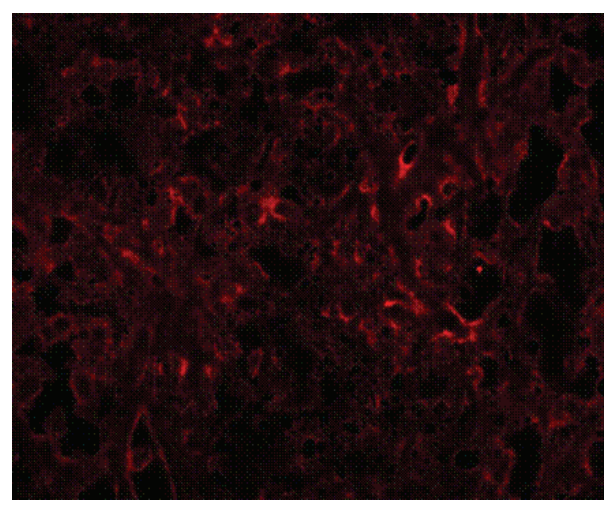

(a)

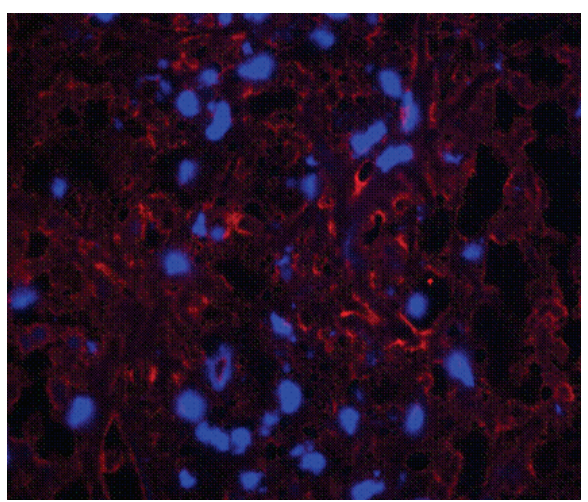

(b)

FIGURE 4: DU145 tumour tissue section stained with a monoclonal anti- $\alpha_{5} \beta_{1}$ antibody (a) and costained with DAPI (b) allowing identification of the cell nucleus. Positive $\alpha_{5} \beta_{1}$ expression in orange and DAPI staining in blue.

TABLE 2: Binding affinity $\left(K_{i}\right)$ of the different compounds tested using the immobilized integrins and ${ }^{125}$ I-echistatin as radioligand (in bold average and standard deviation of the mean are given).

\begin{tabular}{|c|c|c|c|}
\hline Peptide & $\alpha_{5} \beta_{1}[\mathrm{nM}]$ & $\alpha_{v} \beta_{3}[\mu \mathrm{M}]$ & $\alpha_{I I b} \beta_{3}[\mu \mathrm{M}]$ \\
\hline \multirow{4}{*}{ H-C* RRETAWAC* ${ }^{*}-\mathrm{OH}$} & 10 & & \multirow{4}{*}{ n.d. } \\
\hline & 3.9 & $>50(n-2)$ & \\
\hline & 2.1 & $>50(n=2)$ & \\
\hline & $5.3 \pm 4.1$ & & \\
\hline \multirow{3}{*}{ H-C ${ }^{*}$ ARETAWAC ${ }^{*}-\mathrm{OH}$} & 39.000 & & \multirow{3}{*}{ n.d. } \\
\hline & 40.000 & n.d. & \\
\hline & $40.000 \pm 1.000$ & & \\
\hline \multirow{3}{*}{ H-C ${ }^{*}$ RAETAWAC* $-\mathrm{OH}$} & 17 & & \multirow{3}{*}{ n.d. } \\
\hline & 15 & n.d. & \\
\hline & $16 \pm 1$ & & \\
\hline H-C ${ }^{*}$ RRATAWAC $^{*}-\mathrm{OH}$ & $>50.000(n=2)$ & n.d. & n.d. \\
\hline \multirow{3}{*}{ H-C ${ }^{*}$ RREAAWAC $^{*}-\mathrm{OH}$} & 8.000 & & \multirow{3}{*}{ n.d. } \\
\hline & 11.000 & n.d. & \\
\hline & $10.000 \pm 2.000$ & & \\
\hline H-C*RRETAAAC* $-\mathrm{OH}$ & $>50.000(n=2)$ & n.d. & n.d. \\
\hline \multirow{3}{*}{ FProp-C ${ }^{*}$ RRETAWAC ${ }^{*}-\mathrm{OH}(1)$} & 41 & & \multirow{3}{*}{$>50(n=2)$} \\
\hline & 47 & $>50(n=2)$ & \\
\hline & $44 \pm 3$ & & \\
\hline \multirow{3}{*}{ FProp-C ${ }^{*}$ RRETAWAC $^{*}-\mathrm{OH}(2)$} & 127 & & \multirow{3}{*}{$>50(n=2)$} \\
\hline & 26 & $>50(n=2)$ & \\
\hline & $77 \pm 50$ & & \\
\hline
\end{tabular}

structure with high binding affinity that was found for integrin $\alpha_{5} \beta_{1}$ and low binding affinity for integrins $\alpha_{v} \beta_{3}$ and $\alpha_{I I b} \beta_{3}$. The $\left[{ }^{18} \mathrm{~F}\right]$ labelling reaction proceeded with the racemic mixture of $2-\left[{ }^{18} \mathrm{~F}\right]$ fluoropropionic acid ester, thereby resulting in two diastereomeric radiolabelled peptides. However, our in vitro binding studies demonstrated no significant difference in the binding affinity for the integrin $\alpha_{5} \beta_{1}$ between both diastereomers; thus, for all further experiments, a separation of the radiolabelled diastereomeric products was not carried out. Due to the fact that this peptide sequence resulted from a phage display library screening, it could be expected that the $\mathrm{N}$ - and $\mathrm{C}$-terminal end do not have great influence on the binding affinity. In fact, the binding affinity for the N-terminally modified peptide decreased only by a factor $<10$. In contrast, with exception of $\mathrm{Arg}^{3}$, all amino acids of the peptide sequence are important for high affinity binding to the integrin $\alpha_{5} \beta_{1}$ with the most dramatic reduction found for $\mathrm{Glu}^{4}$ and $\operatorname{Trp}^{7}$, as shown by binding studies with the corresponding Ala-modified analogs.

For the preclinical evaluation, human melanoma M21 and M21-L cells as well as human prostate carcinoma DU145 cells have been used. The first cell line has been introduced to control receptor specificity because it is known that M21 cells show high integrin $\alpha_{v} \beta_{3}$ expression, whereas M21-L cells 


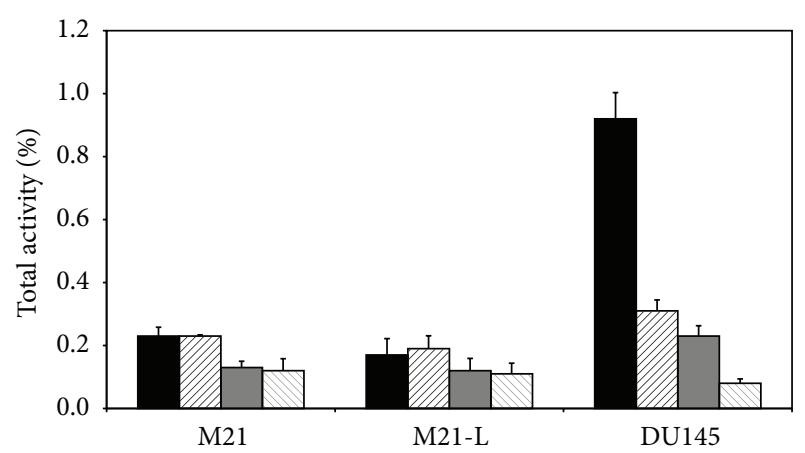

Figure 5: Cell uptake studies of $\left[{ }^{18} \mathrm{~F}\right]$ FProp-C ${ }^{*}$ RRETAWAC ${ }^{*}-\mathrm{OH}$ using human melanoma M21 and M21-L as well as human prostate carcinoma DU145 cells. Black: cell bound activity, black striped: cell bound activity blocked, grey: internalised activity, and grey striped: internalised activity blocked.

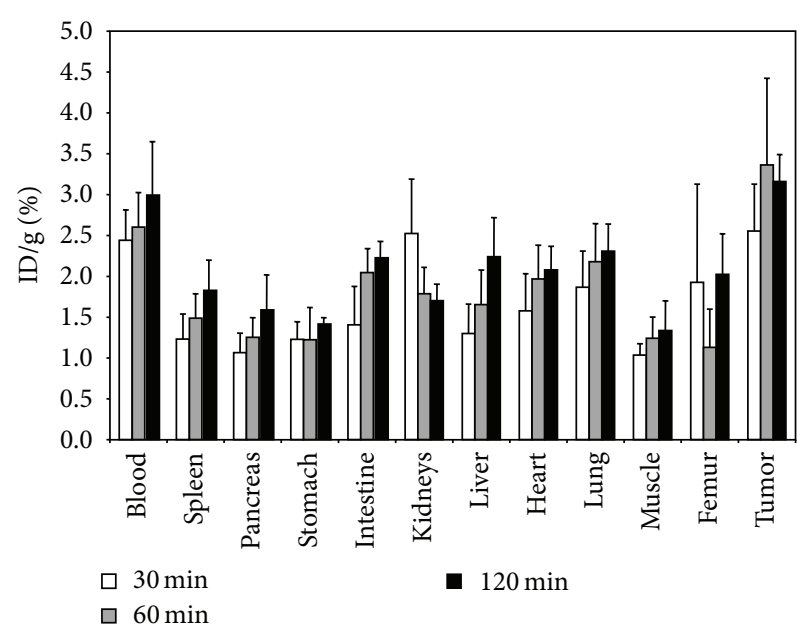

FIGURE 6: Biodistribution of $\left[{ }^{18} \mathrm{~F}\right]$ FProp-C $\mathrm{C}^{*}$ RRETAWAC ${ }^{*}-\mathrm{OH}$ in nude mice bearing DU145 human prostate carcinoma at different time points postinjection.

have low integrin $\alpha_{v} \beta_{3}$ expression [22]. The latter was chosen because the cell line was used for the evaluation of another $\alpha_{5} \beta_{1}$ inhibitor [23], and, therefore, it was assumed that the cells are integrin $\alpha_{5} \beta_{1}$-positive. This has been confirmed by our FACS analysis. More importantly, the experiments also showed low $\alpha_{5} \beta_{1}$ density for M21 and M21-L cells, whereas, besides high integrin $\alpha_{5} \beta_{1}$ expression, low $\alpha_{v} \beta_{3}$ expression was found for DU145 cells. Thus, by using these three cell lines, we included all necessary controls for the in vitro and in vivo evaluation and our cell uptake studies demonstrated receptor selective binding and internalisation of $\left[{ }^{18} \mathrm{~F}\right]$ FProp$\mathrm{C}^{*}$ RRETAWAC* $-\mathrm{OH}$ only for the DU145, therefore nicely confirming the receptor binding studies on isolated purified integrins.

In contrast, in the in vivo biodistribution studies using the DU145 tumour xenograft model, unexpected results were found. At first glance, it was found reasonable that tracer

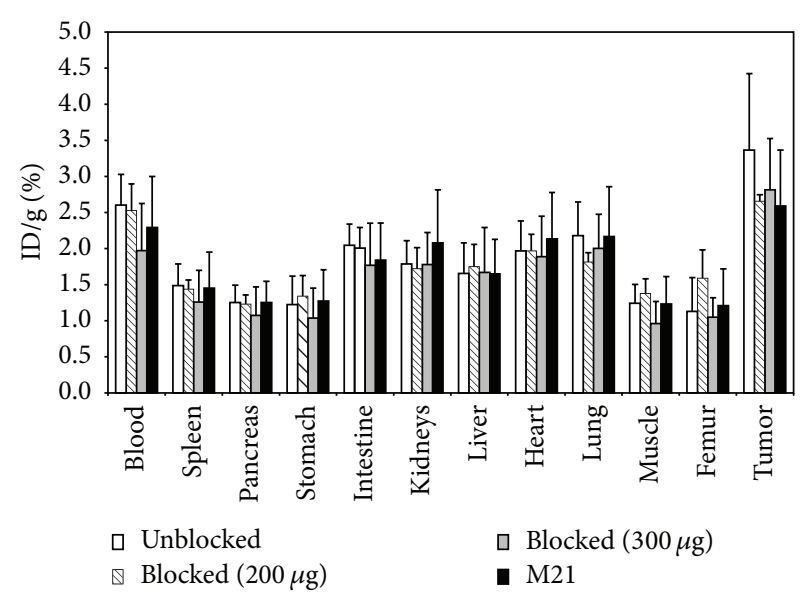

FIgURE 7: Comparison of the biodistribution data with data from blocking of $\left[{ }^{18} \mathrm{~F}\right]$ FProp-C ${ }^{*}$ RRETAWAC ${ }^{*}-\mathrm{OH}$ uptake by coinjection of $200 \mu \mathrm{g}$ or $300 \mu \mathrm{g} \mathrm{H}-\mathrm{C}^{*} \mathrm{RRETAWAC}^{*}$-OH per mouse in nude mice bearing DU145 human prostate and biodistribution in M21-bearing nude mice (which do not express $\alpha_{5} \beta_{1}$ ).

uptake in the tumour was the highest of all organs, but the uptake of the radiopeptide could not be decreased or substantially blocked using increasing amounts of the nonradioactive lead structure $\mathrm{H}-\mathrm{C}^{*}$ RRETAWAC* ${ }^{*} \mathrm{OH}$. Moreover, the tracer uptake in the negative control tumour M21 was comparably high. In addition, the radioactivity concentration in the blood was only slightly lower, resulting in unfavourable tumour/blood ratios. Despite the fact that the tracer uptake in tumour was the highest, the other tumour/background ratios were only slightly above one. At the moment, we do not have an intelligible explanation for this finding, especially, having in mind that the amount of blood protein bound radioactivity found by incubating $\left[{ }^{18} \mathrm{~F}\right]$ FProp-C ${ }^{*}$ RRETAWAC ${ }^{*}-\mathrm{OH}$ with human serum was low and metabolic stability was high. It is tempting to speculate that the main metabolic degradation of $\left[{ }^{18} \mathrm{~F}\right]$ FProp-C ${ }^{*}$ RRETAWAC ${ }^{*}$-OH does not occur in blood but in other organs such as the liver. Clearly, additional experiments are needed to study the metabolism of $\left[{ }^{18} \mathrm{~F}\right]$ FProp$\mathrm{C}^{*}$ RRETAWAC ${ }^{*}-\mathrm{OH}$ in more detail. However, such analyses of organ homogenates were beyond the scope of the current work.

In summary, despite the high selectivity and affinity for integrin $\alpha_{5} \beta_{1}$, selective uptake in receptor-positive cells, and high metabolic stability in human serum in vitro, $\left[{ }^{18} \mathrm{~F}\right] \mathrm{FProp}-$ $\mathrm{C}^{*}$ RRETAWAC ${ }^{*}-\mathrm{OH}$ was not suitable to specifically target $\alpha_{5} \beta_{1}$-positive tumour cells in vivo. Thus, this tracer is not applicable for the noninvasive determination of this receptor and the related angiogenic processes. The Kessler group introduced nonpeptide $\alpha_{5} \beta_{1}$ antagonists based on an azaglycine scaffold and conjugated NODAGA for labelling with ${ }^{68}$ Ga-gallium [14]. In their study, a competitive solid phase integrin binding assay demonstrated high binding affinity and selectivity to integrin $\alpha_{5} \beta_{1}$, but in contrast to our data, this compound allowed receptor specific visualisation of the $\alpha_{5} \beta_{1}$-positive tumour, which was demonstrated using a murine tumour model of mice bearing an $\alpha_{5} \beta_{1}$-positive 
human colon carcinoma (RKO) on the one flank and the $\alpha_{v} \beta_{3}$-positive human melanoma (M21) on the other flank.

\section{Conclusion}

In conclusion, $\left[{ }^{18} \mathrm{~F}\right]$ FProp- $\mathrm{C}^{*} \mathrm{RRETAWAC}^{*}-\mathrm{OH}$ could be synthesised straightforward using standard SPPS protocols and labelled in sufficient yields by using 4-nitrophenyl$(R S)-2-\left[{ }^{18} \mathrm{~F}\right]$ fluoropropionate. The modified peptide showed comparable selectivity and high affinity to integrin $\alpha_{5} \beta_{1}$, which was similar to that of the lead compound, and high stability in serum together with receptor specific uptake in vitro. In contrast, in vivo studies did not suggest receptor specific binding to integrin $\alpha_{5} \beta_{1}$-positive tumours, possibly due to severe metabolic degradation. Further experiments are needed to study the in vivo metabolism of this peptide and to develop improved radiopeptide candidates derived from the promising $\mathrm{C}^{*} \mathrm{RRETAWAC}^{*}-\mathrm{OH}$ sequence that are suitable for PET imaging of $\alpha_{5} \beta_{1}$ expression in vivo.

\section{Conflict of Interests}

The authors declare that there is no conflict of interests regarding the publication of this paper.

\section{Acknowledgments}

Nihon Medi-Physics Co., Ltd., Tokyo, Japan, is acknowledged for the financial support. Dr. Bettina Sarg, Division of Clinical Biochemistry, Innsbruck Medical University, is acknowledged for carrying out the LC-MS analysis. The authors thank Dr. Frank Hampel and Margarete Dzialach, Department of Chemistry and Pharmacy, Chair of Organic Chemistry, Friedrich-Alexander University Erlangen-Nürnberg, for the high resolution ESI-TOF mass spectra. Iris Torres and Adelina Haller are acknowledged for the skillful technical assistance. David A. Cheresh, The Scripps Research Institute, La Jolla, CA, is acknowledged for providing the human melanoma M21 and M21-L cells. The authors also thank Simone Mader for the help with flow cytometric analysis.

\section{References}

[1] J. Welti, S. Loges, S. Dimmeler, and P. Carmeliet, "Recent molecular discoveries in angiogenesis and antiangiogenic therapies in cancer," The Journal of Clinical Investigation, vol. 123, no. 8, pp. 3190-3200, 2013.

[2] M. Petrillo, G. Scambia, and G. Ferrandina, "Novel targets for VEGF-independent anti-angiogenic drugs," Expert Opinion on Investigational Drugs, vol. 21, no. 4, pp. 451-472, 2012.

[3] K. Seystahl and M. Weller, "Is there a world beyond bevacizumab in targeting angiogenesis in glioblastoma?" Expert Opinion on Investigational Drugs, vol. 21, no. 5, pp. 605-617, 2012.

[4] A. Iagaru and S. S. Gambhir, "Imaging tumor angiogenesis: the road to clinical utility," American Journal of Roentgenology, vol. 201, no. 2, pp. W183-W191, 2013.

[5] R. Haubner, A. J. Beer, H. Wang, and X. Chen, "Positron emission tomography tracers for imaging angiogenesis," European
Journal of Nuclear Medicine and Molecular Imaging, vol. 37, supplement 1, pp. S86-S103, 2010.

[6] R. Haubner, D. Finsinger, and H. Kessler, "Stereoisomeric peptide libraries and peptidomimetics for designing selective inhibitors of the $\alpha_{v} \beta_{3}$ integrin for a new cancer therapy," Angewandte Chemie-International Edition, vol. 36, no. 13-14, pp. 1374-1389, 1997.

[7] F. C. Gaertner, H. Kessler, H.-J. Wester, M. Schwaiger, and A. J. Beer, "Radiolabelled RGD peptides for imaging and therapy," European Journal of Nuclear Medicine and Molecular Imaging, vol. 39, supplement 1, pp. S126-S138, 2012.

[8] B. Garmy-Susini and J. A. Varner, "Roles of integrins in tumor angiogenesis and lymphangiogenesis," Lymphatic Research and Biology, vol. 6, no. 3-4, pp. 155-163, 2008.

[9] G. H. Mahabeleshwar, W. Feng, D. R. Phillips, and T. V. Byzova, "Integrin signaling is critical for pathological angiogenesis," The Journal of Experimental Medicine, vol. 203, no. 11, pp. 2495-2507, 2006.

[10] K. L. Goh, J. T. Yang, and R. O. Hynes, "Mesodermal defects and cranial neural crest apoptosis in $\alpha 5$ integrin-null embryos," Development, vol. 124, no. 21, pp. 4309-4319, 1997.

[11] S. Kim, K. Bell, S. A. Mousa, and J. A. Varner, "Regulation of angiogenesis in vivo by ligation of integrin $\alpha_{5} \beta_{1}$ with the central cell-binding domain of fibronectin," American Journal of Pathology, vol. 156, no. 4, pp. 1345-1362, 2000.

[12] N. J. Boudreau and J. A. Varner, "The homeobox transcription factor Hox D3 promotes integrin $\alpha_{5} \beta_{1}$ expression and function during angiogenesis," The Journal of Biological Chemistry, vol. 279, no. 6, pp. 4862-4868, 2004.

[13] D. Heckmann, A. Meyer, B. Laufer, G. Zahn, R. Stragies, and H. Kessler, "Rational design of highly active and selective ligands for the $\alpha_{5} \beta_{1}$ integrin receptor," ChemBioChem, vol. 9, no. 9, pp. 1397-1407, 2008.

[14] S. Neubauer, F. Rechenmacher, A. J. Beer et al., "Selective imaging of the angiogenic relevant integrins $\alpha_{5} \beta_{1}$ and $\alpha_{v} \beta_{3}$," Angewandte Chemie-International Edition, vol. 52, no. 44, pp. 11656-11659, 2013.

[15] E. Koivunen, B. Wang, and E. Ruoslahti, "Isolation of a highly specific ligand for the $\alpha_{5} \beta_{1}$ integrin from a phage display library," Journal of Cell Biology, vol. 124, no. 3, pp. 373-380, 1994.

[16] E. D. Bergmann and I. Blank, "Studies on organic fluorine compounds. Part I. Some esters of monofluoroacetic acid and related compounds," Journal of the Chemical Society, vol. 75, pp. 3786-3788, 1953.

[17] R. Haubner, B. Kuhnast, C. Mang et al., " $\left[{ }^{18}\right.$ F]Galacto-RGD: synthesis, radiolabeling, metabolic stability, and radiation dose estimates," Bioconjugate Chemistry, vol. 15, no. 1, pp. 61-69, 2004.

[18] M. Schottelius, J. C. Reubi, V. Eltschinger, M. Schwaiger, and H.J. Wester, "N-terminal sugar conjugation and C-terminal Thrfor-Thr(ol) exchange in radioiodinated $\mathrm{Tyr}^{3}$-octreotide: effect on cellular ligand trafficking in vitro and tumor accumulation in vivo," Journal of Medicinal Chemistry, vol. 48, no. 8, pp. 27782789, 2005.

[19] S. Guhlke, H. H. Coenen, and G. Stöcklin, "Fluoroacylation agents based on small n.c.a. $\left[{ }^{18} \mathrm{~F}\right]$ fluorocarboxylic acids," Applied Radiation and Isotopes, vol. 45, no. 6, pp. 715-727, 1994.

[20] O. Prante, J. Einsiedel, R. Haubner et al., "3,4,6-Tri-O-acetyl2-deoxy-2- $\left[{ }^{18} \mathrm{~F}\right]$ fluoroglucopyranosyl phenylthiosulfonate: a thiol-reactive agent for the chemoselective ${ }^{18} \mathrm{~F}$-glycosylation of peptides," Bioconjugate Chemistry, vol. 18, no. 1, pp. 254-262, 2007. 
[21] R. Haubner, S. Maschauer, and O. Prante, "PET-radiopharmaceuticals for imaging integrin expression: tracers in clinical studies and recent developments," BioMed Research International, vol. 2014, Article ID 871609, 2014.

[22] B. Felding-Habermann, B. M. Mueller, C. A. Romerdahl, and D. A. Cheresh, "Involvement of integrin $\alpha_{v}$ gene expression in human melanoma tumorigenicity," The Journal of Clinical Investigation, vol. 89, no. 6, pp. 2018-2022, 1992.

[23] D. L. Livant, R. K. Brabec, K. J. Pienta et al., "Anti-invasive, antitumorigenic, and antimetastatic activities of the PHSCN sequence in prostate carcinoma," Cancer Research, vol. 60, no. 2, pp. 309-320, 2000. 


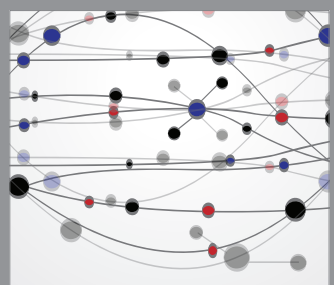

The Scientific World Journal
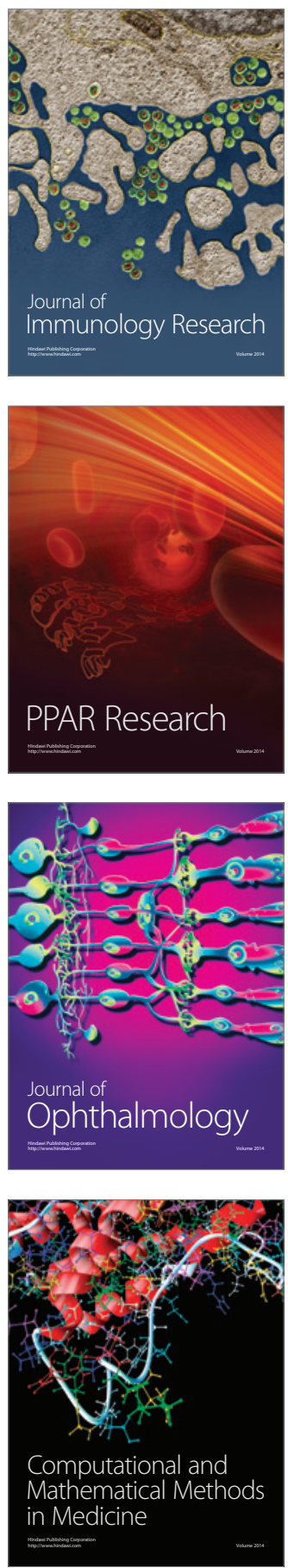

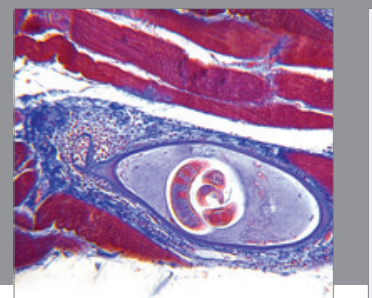

Gastroenterology

Research and Practice
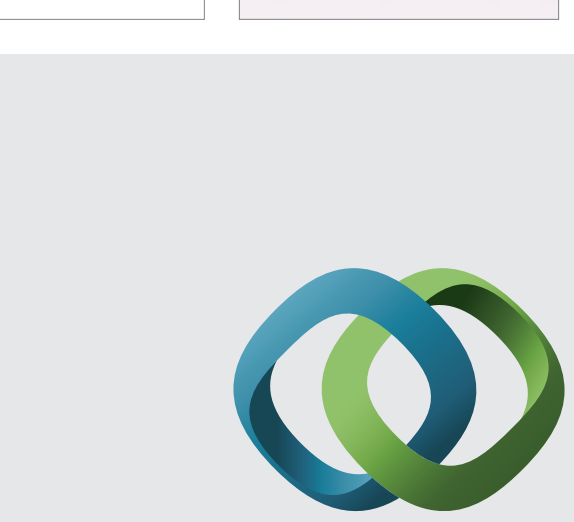

\section{Hindawi}

Submit your manuscripts at

http://www.hindawi.com
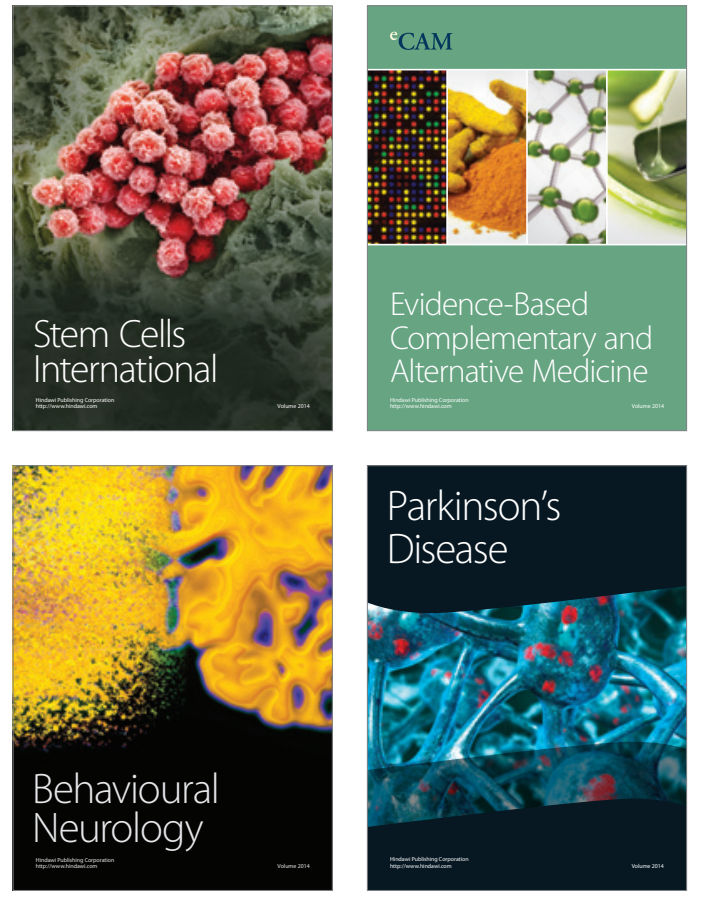
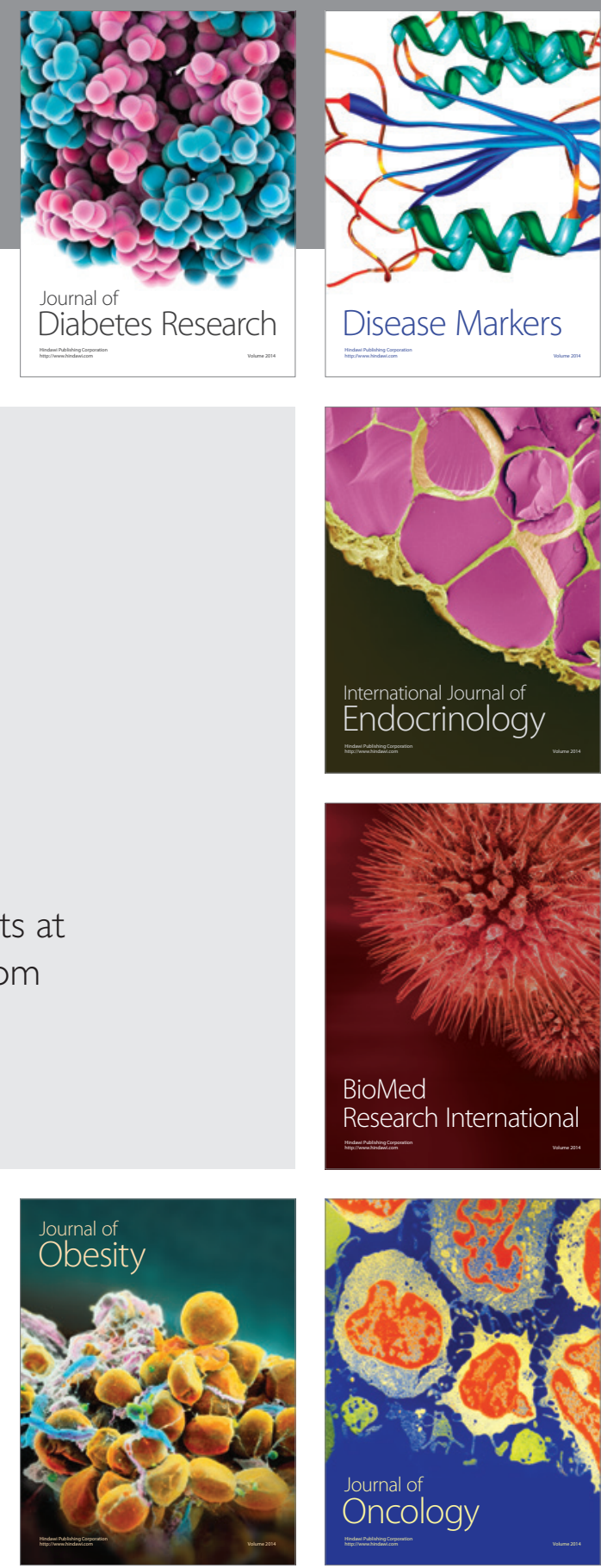

Disease Markers
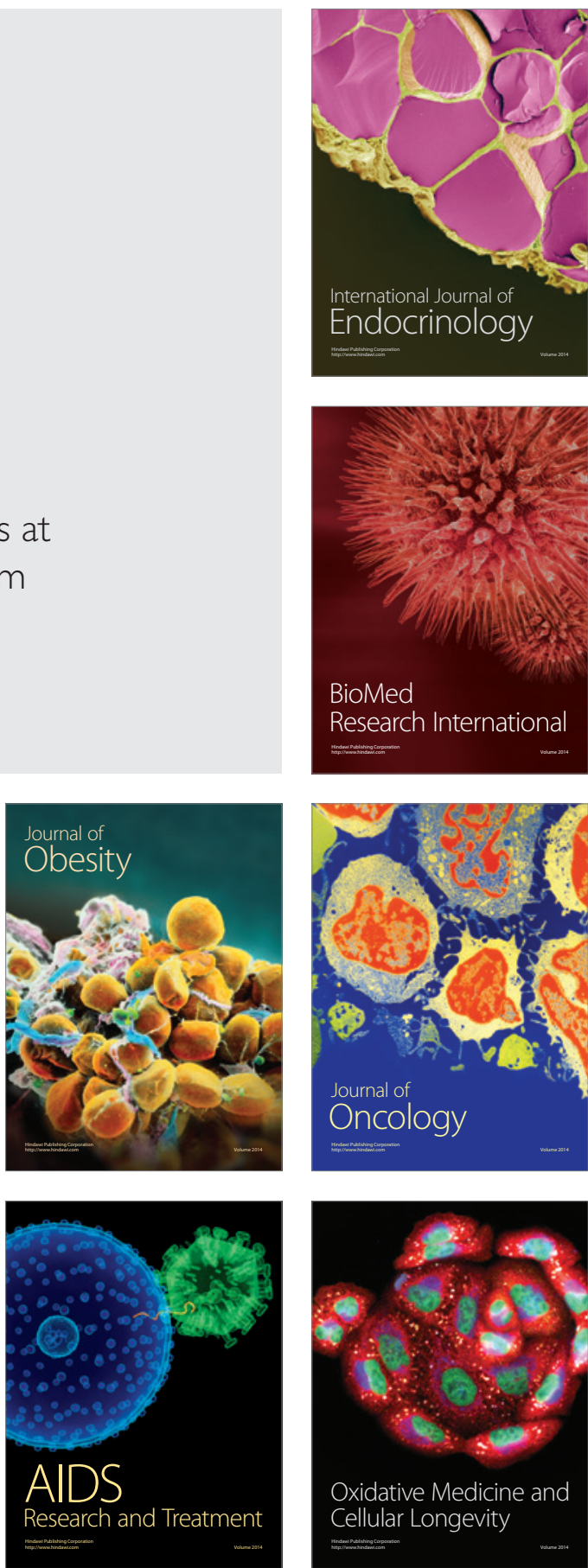